\title{
CAFUAS, GUETOS E SANTUÁRIOS - ATUALIZAÇÃO DO SAGRADO NUM ARTISTA ICONOCLASTA: PRODUÇÃO, RECEPÇÃO E REPERCUSSÃO DA OBRA DE TOM ZÉ \\ José Valdimir Araújo Filho
}

\author{
Professor graduado em Letras, especializado em Literatura pela PUC. Pesquisa realizada sob orientação da \\ Profa Ms. Fabiana Félix do Amaral.
}

\section{Resumo}

O presente artigo focaliza-se na figura solitária e peculiar de artistas que destoam dos movimentos estéticos em bloco, dominantes ou vanguardistas, aqui ilustrado pelo músico Tom Zé. O objetivo desse artigo é analisar o propósito de um projeto artístico que inclui, na performance, o exagero da auto-referencialidade como procedimento para intensificar o alcance do próprio discurso.

Os referenciais teóricos que norteiam a pesquisa são encontrados nos apontamentos de Antonio Gramsci e Nestor Garcia Canclini, do primeiro na sistematização da Filosofia da Práxis e do segundo nos estudos das Culturas Híbridas. Os dois esclarecem o papel de um novo tipo de intelectual e artista imbricados nas seguintes dimensões: a do intelectual orgânico em relação com o oprimido, quando estabelece empatia a partir de uma autêntica sintonia, na qual o intelectual percebe no outro a potência e, dessa forma, valorizando o saber popular que lhe confere identidade, lutando pela socialização do conhecimento com vistas ao descortinamento de um novo horizonte ético-político; por outro lado, a obra do artista moderno inclui a celebridade individual, a conversão da história imediata do artista e a textualização da vida social, como estratégias para ampliar o alcance do discurso, para essa breve pesquisa interessam os aspectos político e pedagógico dessas estratégias.

O esforço desse artigo consiste em aproveitar os esclarecimentos dos teóricos acima citados para ilustrar, com a obra e a trajetória de Tom Zé, uma espécie de artista complexo que, ao perseguir o prevalecimento do seu ideal estético, incorporou as adversidades dos que enfrentam e resistem aos apelos da massificação; dos que ousaram entrar em confrontos com a indústria cultural e, não raro, com o cenário político e social.

Palavras-chave: Tom Zé; música; processos mediáticos e culturais

\section{Resumen}

El presente artículo focaliza la figura sola y peculiar de artistas que se diferencian de los movimientos estéticos en bloques, dominantes o de vanguardia, aquí ilustrados por el músico Tom Zé. El objetivo es analizar el propósito de un proyecto artístico que incluye en el desempeño el exagero de la autorreferencialidad como procedimiento para intensificar el alcance del propio discurso.

Los marcos teóricos que guiaron la investigación fueron buscados en los apuntes de Antonio Gramsci y Nestor Garcia Canclini, del primero en la sistematización de la Filosofía de la 
Praxis y, del segundo, en los estudios de las Culturas Híbridas. Los dos esclarecen el papel de un nuevo tipo de intelectual y artista entretejidos en las siguientes dimensiones: la del intelectual orgánico respecto al oprimido, cuando establecen empatía desde una auténtica sintonía, en la cual el intelectual percibe en el otro la potencia valorando, de esa forma, el saber popular que le atribuye identidad y luchando por la socialización del conocimiento con el objetivo de clarificar un nuevo horizonte ético-político; por otra parte la obra del artista moderno incluye la celebridad individual, la conversión de la historia inmediata del artista, las mensajes textuales de la vida social, como estrategias para ampliar el alcance del discurso, aquí interesando lo político e lo pedagógico.

El esfuerzo de ese artículo consistió en aprovechar los esclarecimientos de los teóricos arriba citados para ilustrar, con la obra y la trayectoria de Tom Zé, una especie de artista complejo que, al perseguir que prevaleciera su ideal estético, incorporó las adversidades de los que enfrentan y resisten a los recursos de la masificación; de los que se atrevieron a entrar en enfrentamientos con la industria cultural y, no raro, con el escenario político y social.

Palabras clave: Tom Zé; música; procesos de los medios de comunicación y culturales.

\section{Abstract}

This article focuses on figure of the solitary unusual artists who highlight from the block of artistic movements of dominant or vanguard aesthetic, here illustrated by the musician Tom Zé. The goal is to analyze the purpose of an artistic project that includes in the performance exaggeration of the self references as a procedure to intensify the power of speech.

The underlying theoretical thought of this research were obtained in Antonio Gramsci and Nestor Garcia Canclini's studies; from the first one the systemization of philosophy of Praxis, from the second one Hybrid Culture studies. The two clarify the role of a new type of intellectual and artist interwoven in the following dimensions: the intellectual's organic relationship with the oppressed, when establish empathy from a real line, in which intellectual realizes another power, thereby enhancing know popular conferring identity and struggling for socializing knowledge with a view to show up a new political ethical horizon; on the other hand the work of modern artist includes individual celebrity behavior, immediate conversation of artist's history, the verbalization of social life, both as strategies to expand the reach of speech that here concerns the political and educational achieving.

The effort of this article was to leverage the clarifications of the abovementioned theoretical background illustrated with Tom Zés work and career, as a kind of complex artist, to pursue to prevail his aesthetic ideal, he assumed the odds of that kind of people who faces and resists to the appeals of the mass culture, which implies in confrontation with the cultural industry and regularly with political and social landscape.

Keywords: Tom Zé; music; media and cultural processes 


\section{Introdução}

Entender um fenômeno cultural pressupõe certo envolvimento do observador com o cerne da questão analisada, mas, ainda, um distanciamento crítico e reflexivo que propicie acrescentar sob determinado prisma um ponto de vista que contribua e amplie o entendimento proposto. Aqui a atenção se volta para a figura do artista contemporâneo inserido no contexto do mercado cultural, particularmente a exceção em meio a um grupo de artistas, ou seja, do momento em que ocorre uma identificação que associe o artista a determinado movimento até que o mesmo rompa ou é expelido por não comportar-se ou comungar-se com as características que o aliavam a um conjunto que se estabeleceu. No entanto, a figura que se isola comporá com outras, ao longo da história, um conjunto de seres desagregadores, mas necessários para impulsionar o movimento desenvolvedor.

O personagem que se elege é o músico, compositor e letrista, Tom Zé; sua trajetória histórica pontua as reflexões deste artigo, especialmente porque os diferentes contextos temporais e espaciais nos quais este está inserido compõem um material de excepcional valor para a pesquisa, material ainda distante de se vislumbrar sequer o início da sua saturação, em particular da figura que dá ensejo as reflexões aqui propostas.

As questões levantadas pela elaboração desse estudo têm sua origem na seguinte hipótese: a cultura se desenvolve não somente pela articulação de pensadores e criadores numa comunhão de idéias, mas especialmente pela figura de um elemento incômodo e estranho que questiona o que se constitui como a própria vanguarda. As implicações em abrigar tal elemento resvalam em diferentes desdobramentos, por diferentes motivos: precaução de uma classe que se empenha em manter os ideários estéticos fundados por ela; desinteresse mercadológico da indústria cultural. Os reflexos destes dois posicionamentos incidem na ponta cabal para a sobrevivência de um artista, o público. O fenômeno excepcional é a sobrevivência artística - incansável e ativa - diante de tantos percalços, por vezes intransponível ao ser humano comum.

Quais as implicações da permanência ativa de uma figura artística como a do músico Tom Zé no cenário cultural brasileiro, antes e depois de ser resgatado do ostracismo pelo mercado fonográfico norte-americano? Qual a importância de uma produção que conjuga o erudito e o popular, o sagrado e o profano, em um fenômeno singular como a canção, emancipada do tropicalismo, de trejeitos arlequinais? De que modo esse artista sintetiza um discurso político-pedagógico formalizado em músicas de pouco apelo às massas (para quem talvez devessem, acima de tudo, ser dirigidas) e que tem maior absorção pelas classes hegemônicas, inclusive ao atravessar fronteiras? Qual o sentido de sua penetração no jovem público universitário, que lotam os seus shows e compram seus discos, quais os ecos desta difusão? 
As questões acima norteiam o presente estudo, amparado por um referencial teórico extenso, do qual se destaca a Filosofia da Práxis de Antonio Gramsci (citado por SEMERARO, 2006), quando foca a figura do artista, do novo intelectual ou do intelectual orgânico, como elemento chave para a emancipação dos subjugados socialmente. A especificação das relações entre artistas, intermediários e público é fornecida por Nestor Garcia Canclini (2006), da obra em que o antropólogo argentino analisa as transformações das relações entre tradição, modernismo cultural e modernização socioeconômica no âmbito latino-americano. Outra referência importante, agora para o mapeamento do que diz respeito às especificidades de uma historiografia musical para a análise de um fenômeno neste campo, encontra-se na obra do historiador Marcos Napolitano (2002).

As fontes de pesquisa são diversas: entrevistas, ensaios, artigos, textos jornalísticos, produção fonográfica e vídeográfica, depoimentos em sites e blogs. Não bastasse a atualidade dos depoimentos, a oportunidade de ainda freqüentar as apresentações do artista que ilustra este estudo, enquanto observador e expectador, fornecem rico material recortado para atender os limites do gênero que materializa o conhecimento alcançado. A partir de uma análise das fontes levantadas para entender o objeto desta pesquisa, o procedimento metodológico que se busca atingir é predominantemente do Materialismo Dialético, no qual objeto e sujeito estão estreitamente relacionados dialeticamente; metodologia facilitada, nesta pesquisa, pelo objeto pulsante analisado e pela figura ativa, mais uma vez, que o ilustra.

Implodindo os séculos: artistas desagregadores

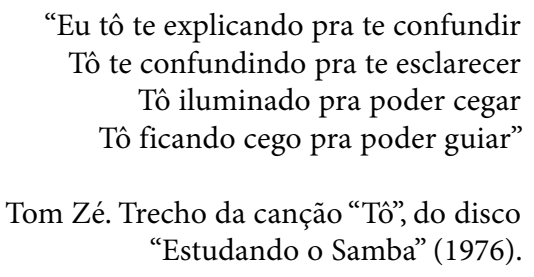

A História dá conta dos movimentos sociais tensivos que envergam a vara da tolerância até o limite, o resultado pode ser o retorno ao estado anterior ou a envergadura ultrapassa o suportável e quebra. Ainda que os ânimos se acomodem, alguém produz uma acha violenta na madeira, o cristal trinca, os humores estremecem e o retorno não é completo, o produto avariou; e aquilo que provocou a desestabilização, ainda que derrotado no seu fim, terá cumprido uma parcela considerável que se acumula a um e mais outro desestabilizador e a mudança almejada é adiada, até que um dia pode acontecer, sob os créditos de outro anti-herói, um derradeiro avatar.

Declinando de um roteiro diacrônico para analisar o efeito de figuras da cultu- 
ra que provocam, desagregam, desestabilizam, pode-se tangenciar um estudo sincrônico e citar algumas delas mais conhecidas, como um Gregório de Matos, um Oswald de Andrade, um Zé Celso Martinez Correa, um Oscar Wilde, um Serge Gainsbourg, um Wally Salomão, um Truman Capote e por último, destes que o Século XXI abriga, banca e dá lucro, os midiáticos Michael Moore e Sacha Baron Cohen, até se deter numa figura da mesma estirpe que sucumbe à pressão dos tradicionalistas, afunda no esquecimento, e foi resgatado do ostracismo pelas mãos do mais improvável benfeitor, o mercado fonográfico norte-americano, a referência é a Tom Zé, cantor e compositor trazido à cena nacional pelo movimento Tropicalista que o não suportou $\mathrm{e}$ negou-lhe o espólio, a partilha da glória não o atingiu como aos demais, hoje amansados pelo mercado que investe altas somas sob a garantia de um retorno econômico e promocional que pode render a quem investe, quando pouco, status cultural.

As figuras anteriormente nomeadas, incluindo Tom Zé, se investem de um personagem para agir, para atuar, para encenar, às vezes permanentemente como um Wally Salomão ou um Zé Celso, todos driblando a própria identidade, muitos a timidez, com variados procedimentos ou disfarces: sob as máscaras do dândi, do arlequim, do irreverente, do cínico, do irônico, do palhaço; todos conferindo a si mesmos uma aura enigmática que atraem platéias como vespeiro a menor aproximação de movimento, o que não lhes garante a permanência sob os holofotes, sequer à vida e, muitas vezes, a mão que aplaude é a mesma que arremessa o tomate. Artistas vigorosos, mentes férteis, intelectos altamente elaborados, características que lhes azeitam a pena, a língua e o corpo, e distraem alfinetando os humores acomodados na hipocrisia, que suporta a derrisão, dificilmente a verdade virulenta sem os floreios da arte.

A cultura letrada no Brasil nunca teve uma penetração efetiva em todas as camadas sociais, no entanto, a canção nacional obteve a proeza de atingir um alto grau de requinte e de popularidade (duas qualidades que dificilmente andam juntas quando se tratam de um produto de massa) impressionantes no Século XX. A Canção no Brasil já se constitui um relevante objeto de pesquisa, desafiando o pesquisador, como afirma o historiador Marcos Napolitano (2002. p.77-78) "a mapear as camadas de sentido embutidas numa obra musical, bem como suas formas de inserção na sociedade e na história”.

O artista Tom Zé sobreviveu e ainda incomoda, a coerência da sua trajetória chama atenção. Estudar um personagem é um risco, pode-se incorrer na pura exaltação ou execração, nenhuma destas alternativas está prevista no estudo aqui proposto, a escolha se deve principalmente devido ao discurso da obra e da penetração desta nas artérias sociais das quais se destacam o público, que toma contato com a hibridização cultural que margeia o popular e o erudito em suas composições, mas, principalmente, porque o aspecto discursivo da obra deste artista reúne elementos de interesse ao que este estudo se propõe a ilustrar com o pensamento de alguns referen- 
ciais teóricos que analisaram os efeitos de personagens ou movimentos de grupo para a evolução do quadro de desigualdade social, econômica e cultural que predomina até hoje. Haja vista que, no Brasil, a penetração do pensamento dos teóricos citados não se dá pelos livros, como dito anteriormente, mas através de ecos disseminados em práticas artísticas de fácil alcance pelas massas, não raro de forma intuitiva. Como no caso da obra de Tom Zé, em que se podem detectar indícios do intelectual subversivo fomentador de uma "inteligência social"; confrontações de questões ético-sociais com os seus contrários; alerta acerca do prejuízo dos abismos intelectual, econômico e social; a disseminação de posturas emancipatórias à submissão sistemática ao capitalismo predatório.

\section{Matrizes \& referências: transitando entre o erudito e o popular}

$$
\begin{array}{r}
\text { "E cuspido, espremido, } \\
\text { petisco de visgo, } \\
\text { forçando a passagem } \\
\text { pela barreira, } \\
\text { sangrando, rasgando, } \\
\text { subindo a ladeira, } \\
\text { orgasmo invertido, } \\
\text { gritei quando vi: } \\
\text { já estava respirando" }
\end{array}
$$

Tom Zé, trecho da letra "Nave Maria”, do disco homônimo de 1984.

O artista Tom Zé cuida sempre de esclarecer que, acima do sensorial, sua música é direcionada para o cognitivo. As performances comprovam tal afirmação do artista que naturalmente acolhe o elemento estranho para introduzi-lo em suas composições, como o ostinato, a dissonância, sons provenientes de instrumentos inventados, às vezes, objetos utilitários retirados dos seus contextos trazidos para o ambiente da música. O procedimento é engenhoso, às vezes, por trás de uma estrutura melódica previsível, o enxerto de uma dissonância soa à frente e retira o espectador de uma possível letargia, da sua passividade, do hábito. Mas, este não é o único elemento, há ainda as músicas, muito freqüentes, cuja provocação se encontra na letra, em mensagens cifradas ou explícitas, inflamadas pela verve panfletária do músico, especialmente quando atua no palco, tudo fruto de um aprendizado que tem intima relação com a sua formação, e estreita coerência com a sua biografia.

A biografia do artista nos dá conta do seu período de formação no interior baiano, na cidade de Irará. Décadas de 1940 e 1950 do século passado, sem energia elétrica, sem cinema, sem televisão, o adolescente tímido freqüentava a escola distante para suprir a educação formal paralelamente a outras vivências igualmente enriquecedoras, com o olhar atento à dinâmica do lugar, das relações, dos artifícios de sobrevivência da população. A atenção voltada aos habitantes nativos, ao migran- 
te permanentemente instalado e aos provisórios andarilhos daquela época, alguns mascates que freqüentavam a feira local seduzindo a população às tentações do consumo de quinquilharias, medicamentos milagrosos e utensílios domésticos. Destes últimos, aguçou a percepção para todos os artifícios de expressão comunicativa que contribuíam para prender a atenção da platéia e persuadi-la de que o produto não era apenas necessário, como urgente a sua aquisição. A marcação do espaço para a cena, impostação da voz, linguagem corporal, elementos então reconhecidos intuitivamente, mais tarde dominados metacognitivamente, compondo um conjunto de referências consideravelmente aproveitadas e reinventadas.

Depois veio o curso formal de música, aonde iria se deparar, entre 1962 e 1967, com uma equipe de professores europeus imigrados especialmente para atuarem na Escola de Música da Universidade Federal da Bahia; a excelência do ensino da música erudita aberta à cena contemporânea e as invenções vanguardistas, entre seus professores na época Ernst Widmer, Walter Smetak, e o dodecafonista Hans Joachim Koellreuter, um excesso para os modestos padrões sócio-econômicos do estado da Bahia.

O desafio de preservar as raízes como importante elemento de composição artística e apropriar-se das mais requintadas das formas musicais resultou a originalidade de Tom Zé. Em uma época em que predominava a canção dramaticamente interpretada pelo cantor de voz impostada com vistas à reação de uma platéia ávida de romantismo ou a chamada fossa, a sua meta consistia em: "por meio de um choque de presentidade [sic]" e "usando um assunto-espelho" fazer com que o "próprio ouvinte e sua circunstância fossem os personagens da cantiga" (TOM ZÉ, 2003: p. 22). Ou seja, o projeto incluía outra relação de subjetividade com o objeto artístico, que previa uma atenção aos temas sociais, em consonância com o quadro latino-americano ao explorar o mesmo gênero, como um Victor Jara ou uma Violeta Parra, a diferença estava em que o músico brasileiro não se limitaria a fundir os ritmos de raiz com os recursos de uma canção agradavelmente melódica para acomodar e emocionar, um discurso engajado que denunciava a dor do oprimido, Tom Zé se mantém sintonizado com todas as vertentes do pop e do erudito contemporâneo e faz uso desses para se comunicar com seu público, imprimindo forte carga irônica nas letras, conferindolhe lucidez crítica e sofisticados arranjos instrumentais, sem se limitar ao que fosse exclusivamente da ordem do erudito ou popular, sem desprezar as duas formações, a da escola da vida e a da escola formal, decantando a primeira e adequando a segunda a seus propósitos. 
Filha da prática, filha da tática, filha da máquina: aproximação com a filosofia da práxis

\author{
"O homem: \\ O doutor exagera e desatina \\ Pois quando o pobre tem no seu repasto \\ O direito a escola e proteína \\ O seu cérebro cresce qual um astro \\ E começa a nascer pra todo lado \\ Jesus Cristo e muito Fidel Castro" \\ Trecho da letra "Desafio", do álbum “Jogos de Armar" de 2001.
}

$\mathrm{Na}$ análise das letras do compositor Tom Zé percebe-se uma estreita consonância com o discurso da Filosofia da Práxis segundo o pensamento de Antonio Gramsci, pensamento este que está impregnado da

\footnotetext{
"convicção de que as lutas libertárias dos "subalternos" revelam-se inconsistentes quando dissociadas de uma reflexão permanente capaz de criar uma própria concepção de mundo sintonizada com as necessidades do tempo e do lugar em que se atua" [grifo próprio]. (SEMERARO, 2006, pág. 9).
}

Gramsci conclama - prevê - um novo intelectual aliado do povo ou fruto dele, com qualidades que o habilita a articular no mesmo indivíduo o cientista, o crítico e o revolucionário, com a missão de refletir acerca de como se dá a inserção de cada membro social no mercado de produção material e econômica, bem como os mecanismos de reprodução simbólica a fim de revelar os artifícios de dominação ideológica da classe hegemônica e apontando os caminhos para o enfrentamento do opressor para que este reconheça a legitimidade da autonomia de cada indivíduo. É o caminho para a emancipação dos subjugados, onde o novo intelectual é um intelectual orgânico, que se coloca uma relação dialética enquanto acolhido e acolhedor, pois estabelece empatia a partir de uma autêntica sintonia com o oprimido percebendo-lhe a potência, desta forma, valorizando o saber popular que lhe confere identidade e lutando pela socialização do conhecimento com vistas ao descortinamento de novo horizonte ético-político.

\title{
Auto-referência como procedimento para autenticar o discurso na obra
}

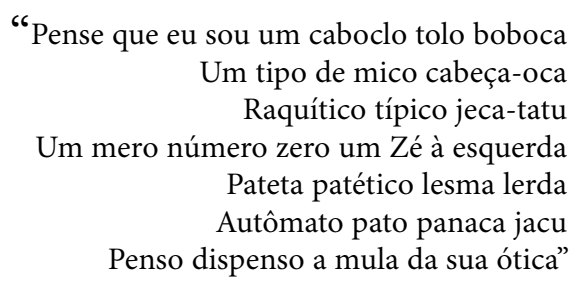

Tom Zé, trecho da letra "Defeito6: ESTETICAR (Estética do Plágio), do disco "Com defeito de fabricação" de 1999. 
As dimensões da obra de Tom Zé não se limitam a letra e a música; a performance, a recepção e a repercussão constituem igual relevância dentro do seu projeto de explorar o cognitivo acima do sensorial, em entrevista, ele conclui o seguinte: "quando entro no palco, imediatamente convoco na platéia o cognitivo. Sem me dar conta, passei a vida treinando essa ligação direta” (TOM ZÉ, 2003: p. 229).

Um pequeno corpus já permite comprovar tal afirmação, por exemplo, o longplay inaugural de sua carreira, "Grande Liquidação" (1968), não deixa dúvida de que ali se anunciava uma figura que atraía a simpatia pelos trejeitos bufões, e dividia pela incisiva e clara crítica ácida à sociedade do consumo exagerado ("Entrei na liquidação/Sai quase liquidado/Vinte vezes, vinte meses/ Eu vendi meu ordenado", da letra de "Sem entrada e sem mais nada"), do individualismo ("são oito milhões de habitantes/ aglomerada solidão/ por mil chaminés e carros/ gaseados a prestação", da letra "São São Paulo, meu amor"), da apatia intelectual agravada pela televisão ("a burrice estão na mesa... refinada, poliglota/ ela é transmitida por jornais e rádios/ mas a consagração/ chegou com o advento da televisão", da letra de "Sabor da Burrice"). Seguem-se os discos de sucesso e participações bem sucedidas nos famosos festivais da televisão, mas o disco de 1973, "Todos os olhos", onde se permite a mais alta expressão lírica, conseqüentemente o menos comunicativo, o direciona para o ostracismo, nessa condição insiste na realização do que viria a se um clássico, o disco "Estudando o Samba" de 1976.

A história é conhecida e emblemática, as gravadoras se desinteressaram pelo projeto artístico pautado na extrema criatividade e no desarranjo do gosto estabelecido. Em entrevista, o músico descreve, avalia e compreende o episódio que culminou no seu afastamento da cena musical:

\footnotetext{
"Fui enterrado profundamente, sim, e depois David Byrne me tirou desse buraco. Esse buraco era muito profundo, era preciso tão cuidadosamente me ignorar, era preciso que uma estrutura de cimento e concreto muito forte estivesse sobre mim, que não fosse possível eu sair dali. Bom, eu só posso pensar isso hoje: 'Por que diabo, será que eu era importante?' Só posso concluir... Puta que pariu, isso aí tem que ser um negócio do tipo: 'Esse cara não pode existir!' Muito bem, agora, na hora que eu, por acaso, começo a ser tão bem-sucedido é o caso de dizer: 'Pô, realmente, eu sou um cara perigoso!' Só posso dizer assim." (REVISTA CAROS AMIGOS, 1999).
}

A má fase cessaria com o interesse do produtor musical norte-americano, David Byrne, e reúne acidentes e acontecimentos que estruturariam um causo ou conto maravilhoso protagonizado por um músico brasileiro. $\mathrm{O}$ produtor pesquisava o samba brasileiro, encomendou todo material do gênero disponível e, no meio dele, estava o disco que sepultou temporariamente o artista, ironicamente os mesmos motivos que o afastou das gravadoras brasileiras, despertou o interesse de David Byrne, que o lançou nos EUA, onde Tom Zé alcançou sucesso e reconhecimento surpreendentes.

Um artista com formação incontestavelmente sólida e sofisticada, sem desprezar o acúmulo da experiência cultural e social em que se insere com um projeto 
pautado na comunicação com a platéia, com o propósito bem definido de atingirlhe a consciência, é de se perguntar, afinal, se o sucesso deste intento, a esta altura, atingiu a expectativa ou tal realização é um projeto que beira o idealismo utópico, mas, uma vez constatada toda a dificuldade que acarretaria tal esforço, sem resvalar no trauma ou frustração esterilizante, a consciência de participação num todo, que compreende outros indivíduos os quais, como conclama Gramsci, aliam o "pessimismo da inteligência com o otimismo da vontade". Sigamos por algumas pistas que orientam a sua ambição desde a opção pelo palco, como quando diz: "Eu faço música po-pu-lar! (escandindo as sílabas) Agora, eu não consegui ainda muito bem, como diz Lao Tsé, aplainar certas angulosidades [sic], arredondar certas circunferências malfeitas" (REVISTA CAROS AMIGOS, 1999), por isso, a constatação de incompletude não inclui o diagnóstico do fracasso, mas o móvel para a investigação permanente e ânimo para novas tentativas.

Em entrevista à revista “Caros Amigos”, contrário à delimitação de um ouvinte elitizado, o compositor defende o seguinte:

\footnotetext{
Desculpe, eu quero falar de uma coisa importante. Vamos ver se sou capaz. A empregada lá de casa, Agostinha; os empregados da farmácia; os amigos do ponto de táxi, converso com essas pessoas, essas pessoas todas são meu público-alvo. Porque o tipo de inteligência a que eu me refiro e que procuro na minha música não é uma inteligência cartesiana, que a universidade ensina. As pessoas do povo têm uma inteligência que a gente ignora, uma inteligência não-cartesiana, nãoaristotélica. Eu trabalho pra elas. Não trabalho pra um fracasso. Não trabalho para a USP. Não trabalho com pessimismo. Eu trabalho com otimismo (REVISTA CAROS AMIGOS, 1999).
}

Ou seja, perseguir uma comunicação ampla e direta não exclui a sofisticação do discurso, não cede em nivelar por baixo, por exemplo, intencionando o desconcerto das expectativas em uma letra prestes a ser gravada, o compositor vai desvendando os procedimentos com os quais pretende tirar a platéia do cômodo acento e provocarlhe a surpresa, sem cair na escatologia grotesca, nem na reles pornografia:

\footnotetext{
Meta sua grandeza no cú, é isso que se está esperando. E se eu fizer uma brincadeira dessa vai ficar interessante porque: Meta sua grandeza no banco da esquina! Vai tomar no verbo, seu filho da letra! Meta sua usura na multinacional! Vai tomar na Virgem, seu filho da Cruz! O resultado é um certo humor, a pessoa se surpreende. Então eu acho que isso pode ser interessante. Vou tentar cantar isso, não como um cantor. Tentar cantar de um jeito que a pessoa ouça isso, que o mais importante seja ela ouvir ${ }^{1}$.
}

Por fim, Tom Zé defende explicitamente a idéia de "que tem outro tipo de inteligência que eu persigo, que é uma inteligência que não é cartesiana, nem mede níveis de QI" (REVISTA CAROS AMIGOS, 1999), o alcance de tal resultado já se repetiu, ainda que ocasionalmente, em platéias hibridas, que misturavam o analfabeto, músicos formados e em formação, o intelectual, sintonizados no gozo do mesmo espetáculo, o Abril Pop Rock em Recife, a se questionar, afinal, quem determina o gosto do público. 
Há ainda a defesa de que o espaço pode ser ocupado pelas diferenças, sem xenofobismo, agradando-se do outro sem perder a identidade, as referências:

\footnotetext{
"É porque o mundo só pode viver bem se tiver o Brasil de um lado, os Estados Unidos do outro; a música brasileira de um lado, a música americana do outro; a música javanesa do outro, a música cubana do outro. Isso precisa, para poder o mundo se organizar com diferenças. A importância disso não é patriotismo, é diferença"'.
}

$\mathrm{Na}$ trajetória do músico de Irará, podem-se catalogar alguns marcos de sua carreira focando na repercussão da própria obra, o modo pelo qual o público, ou variantes de público, segmentados segundo alguns critérios como: grupo social, classe econômica, idade, sexo, escolaridade, preferências ideológicas e culturais, receberam sua música, todos acessados devido à itinerância do próprio artista, como: Irará, a terra natal; Salvador, o primeiro investimento rumo a profissionalização artística; São Paulo, a inevitável vitrine; Estados Unidos e Europa, o resgate e a consagração internacional; o público jovem universitário, reconhecimento de uma obra que não envelheceu; jornalistas e críticos, comprovando que boas críticas não garantem público em massa; produtores e empresários artísticos, ética divergindo com interesses comerciais. Por último, o ciberespaço: sites e blogs, onde explora novas ferramentas de comunicação.

Os habitantes de Irará, especialmente os contemporâneos do músico, o enxergam como o filho da terra, o bem sucedido, mas pouco se relacionam com a obra de Tom Zé, que visita periodicamente o lugar, no qual é reconhecido, relativizando com carinho a limitação que o distancia como artista e o aproxima como pessoa. São Paulo se vincula ao artista em dois momentos, o primeiro com a explosão tropicalista, mas o espólio do movimento de sucesso lhe é negado, o artista ganha fôlego por mais alguns anos, chega a vencer alguns dos famosos festivais de música da TV Record.

Um episódio interessante foi a vitória no IV Festival Record em 1968 com a canção "São São Paulo, Meu Amor”, de letra complexa, ambígua, crítica, mas de refrão melódico de grande apelo emocional, alternando nos versos as expressões "São Paulo, quanta dor" com "São Paulo, meu amor", a primeira delas sintomaticamente ignorada pelo grande público entorpecido de carência afetiva ao repetir insistentemente "meu amor, meu amor, meu amor..." O comentário de Tom Zé é o seguinte: "São São Paulo ... Foi tomado como hino de amor, porque, vocês sabem, tem uma coisa que o gatilho da comunicação às vezes dispara e aí não há jeito de fazer entender o que é que

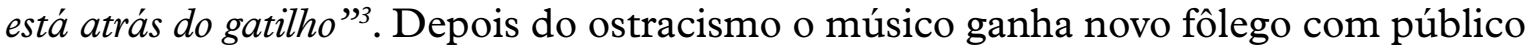
renovado, não mais os contemporâneos dos anos 60 e 70, mas, curiosamente, a faixa etária é a mesma, seriam os netos daquela geração; nas universidades paulistas, são eles que lotam e agitam os shows do, hoje, septuagenário Tom Zé que, como diz uma de suas letras, sofre do mal de juventude e este público jovem não está lá por acaso, o artista também o persegue, como diz: "Vai, vai, Vai, vai, Vai, vai, Brasil, destrói a fé 
do jovem, filho teu. Pra depois poder chamar-lhe adulto. Faz-lhe este insulto, tem uma fase antes do cinismo que a gente pelo menos tem que crer. Antes de se vender, de se render, se corromper" ${ }^{4}$.

Não há como negar a idolatria, mas hoje a performance do músico, ainda que restrita a um público que lhe garante o sucesso local, é mais compreendida, há uma reação aos estímulos provocadores à mesma burguesia que o consome, na qual admite estar inserido. Ainda que se desconfie de que grande parte se limite à graça produzido por uma espécie de arlequim contemporâneo.

A recepção nos EUA é curiosa e nos faz questionar o propósito do artista em atingir o cognitivo da platéia. Admitindo um inglês precário, Tom Zé não se intimida a fim de se fazer entender, arriscando na língua local seu texto agressivo tanto aos agentes que movimentam a máquina cruel do capitalismo, quanto aos que se deixam enredar pela falsidade das promessas de uma nação generosa com os seus habitantes, e poderosa no combate à ameaça a qualquer fator que perturbe tal ordem. $\mathrm{O}$ sucesso de crítica e público surpreende a despeito do ataque virulento à sociedade americana sem metáforas. Ao analisar o fenômeno, o próprio Tom Zé aponta uma chave interpretativa, afirmando tratar-se de sentimento de culpa, portanto, há um fator expiatório que os predispõem a tolerar os ataques verbais do músico. No entanto, não há como negar que a qualidade musical e o poder inventivo, a originalidade desse artista são os elementos que mais atraem tanto a platéia dos EUA com a da Europa, onde também faz sucesso.

Os especialistas em música também são ouvintes determinantes para a permanência de qualquer artista na cena, no caso de Tom Zé; as ameaças políticas que o levaram à prisão pelos militares, depois de o investigarem e o censurarem, permitem analisar que, ironicamente, foram mais generosos do que a classe artística, do que os produtores musicais, do que os donos de gravadoras que o condenaram ao ostracismo, quase o fazendo retornar à terra natal para trabalhar num posto de gasolina.

O contrário também se deu, o produtor David Byrne foi o responsável pela sua consagração nos EUA, mas não sem os contrários aqui mesmo, do Brasil, como diz no documentário "Fabricando Tom Zé" (2007):

\footnotetext{
“... imaginava [o estrangeiro] que tudo era Bossa Nova. A reação deles foi: - Porque Tom Zé, nós temos esta belíssima música, cantores maravilhosos, poetas e cantores clássicos. Tantos deles... porque escolher justo este? Porque você quer trabalhar com essa pessoa estranha? Porque não um de nossos interpretes clássicos da MPB, ou alguém assim?”
}

Byrne conclui ter, aquele artista, mais a ver com a cena contemporânea, com a cena underground nova-iorquina, ou seja, continuava sendo um produto a ser explorado, mas com potencial que extrapolava o exótico, a beleza comportada que se 
adequava perfeitamente ao sucesso.

Outro produtor, o francês Henri Laurence (Gerente de projetos de $\mathfrak{F a z z} \mathcal{E}$ World Music da Sony/BMG France) dá um depoimento revelador no mesmo documentário:

\footnotetext{
"Algumas de suas músicas me fazem chorar. Isso é uma confissão que estou fazendo aqui. Sua música é todas as dimensões da música em uma só. Talvez ele seja todas as dimensões de um homem juntas... ele incorpora todas essas dimensões e convive muito bem com elas. Isso é único!" ${ }^{5}$
}

Ao ser avalizado pelo estrangeiro, legitimado por importantes produtores dos EUA e Europa, o provincianismo brasileiro sintomaticamente revê as posições e alça o músico à condição de gênio musical, de comunicador inconteste. $\mathrm{O}$ tom era de um retorno de Tom Zé, embora ele sempre tenha estado por aqui, produzindo, fazendo shows, contemplando um restrito público cult.

A turma de outra geração de produtores vai se alternando para acolher os delírios artísticos e a extrema disciplina inventiva de Tom Zé: as duas pontas, aqui no Brasil, são Kid Vinil e Charles Gavin, esse último responsável por alguns relançamentos da obra do iraraense e dos inéditos (CD e DVD) que aparecerão ainda em 2009.

As relações com o público são autenticadas pela investidura de uma figura que destoa do artista comum por aspectos como: o cultivo de uma estética da ruptura; ataques ao autoritarismo político e ao mercado da comunicação. A auto-referencialidade intensifica essa diferenciação, mas no caso de Tom Zé, não se trata de induzir apenas o gozo pelo consumo da imagem pública, mas utilizá-la para autenticar o discurso panfletário que põe em circulação. Nesse caso, chama atenção por não se restringir apenas ao ataque ao autoritarismo político, como a maioria dos artistas que fazem deste o eixo das suas argumentações, mas também à indústria cultural igualmente autoritária e manipuladora.

O antropólogo Nestor Garcia Canclini (2006) aponta as entrevistas e declarações ocasionais como parte da obra de um artista, classificando-as como gêneros específicos de cunho extra-literário como alternativo para as operações básicas do discurso massivo que consiste na conversão da história imediata do artista, a textualização da vida social, desde que esta se converteu em mais um dos suportes da arte moderna: a celebridade individual.

Canclini (2006, p. 110) chega mais longe ao rememorar o crítico Octávio Paz quando este chama atenção para a secularização como condutora do infortúnio da consciência, cabendo aos artistas a tarefa de suprir o vácuo produzido pelo distancia- 
mento do sentido da vida pautado na fé religiosa aos artistas modernos que, através das práticas culturais, se utilizando comumente da ironia, distância crítica e re-elaboração lúdica para atingir o público órfão dos mitos, não apenas religiosos, mas também os nacionais, através dos quais se reconhece orgulhosamente. As cafuas, os guetos e os santuários continuam existindo sob novas roupagens e caberia aos artistas e aos intelectuais desestabilizar os responsáveis por tal permanência, o tecnicismo exagerado e a burocracia do Estado, a missão dos intelectuais e artistas seria iluminar com o esplendor das inovações estéticas o quadro de pessimismo ou apatia em que se encontram os subjugados socialmente.

\section{Algumas conclusões}

De todo o exposto acima, pode-se regurgitar algumas reflexões que justificam a inclusão de Tom Zé com um tipo de artista ou intelectual previsto e conclamado por Antonio Gramsci na sistematização de um novo indivíduo participativo proveniente de um povoado à margem da dita civilização moderna, que alimentou seus primeiros anos de formação com a rica vivência e apurada observação da cultura local: as festas populares, as feiras lotadas de comunicadores poéticos e persuasivos, os contadores de histórias, os artistas mambembes itinerantes. Tamanha riqueza não seria desprezada com a formação acadêmica composta por um conjunto de professores europeus que representavam a contemporaneidade da música erudita, ocorrendo uma inusitada apropriação dos dois pólos culturais, fundindo-os sem purismos, sem preconceitos de qualquer ordem.

Pode-se estabelecer a consonância de Tom Zé com o "novo intelectual" gramsciniano: as dimensões críticas, científicas no campo da arte e revolucionárias tanto no artístico como no social, ao denunciar, nas letras das suas canções, reiteradas nas performances e entrevistas, os mecanismos de dominação ideológica da classe hegemônica nas cinco décadas de vida artística, em prol da formação da subjetividade, não só estética, mas igualmente política.

A controvertida relação com a indústria cultural e a perseguição a um público irrestrito nunca foi tranqüila, enfrentando momentos críticos de tensão e desespero. Ao contrário de artistas cults que produzem confortavelmente, deixando a cargo dos produtores culturais a função de mediadores, Tom Zé por muito tempo pouco aproveitou desse tipo de prerrogativa, nem por isso fez concessões estéticas que pudessem facilitar a relação tanto com os intermediadores como com o público. Quando vislumbrou o sucesso em composições como "Xiquexique" (do álbum "Com defeito de fabricação") ou "Menina amanhã de manhã" (do álbum "Estudando o Samba"), longe de preocupar-se das razões ou dos elementos que poderiam contribuir para a massificação da obra, criou a expectativa de que isso viesse a ocorrer. No entanto, a ausência de um sistema de divulgação que colaborasse com a realização de um su- 
cesso foi determinante para enterrar suas expectativas. Associa-se a essa tensa relação com o mercado que denuncia sistematicamente, o autoritarismo político é constantemente atacado pelo compositor sem reservas, independentemente do mercado do qual esteja se beneficiando, seja em solo brasileiro, seja em solo estrangeiro.

As vias de acesso ao público de um artista que se realiza nesta interação de cunho fortemente dialógico são muitas, inclusive já tirando proveito da tecnologia que diminui distâncias e favorecem o debate direto. Os meios escolhidos para a veiculação da música são: o CD, o DVD, o rádio, a televisão e a Internet. As idéias, ou a dissecação dessas, concentradas na poesia de suas letras, permeiam a imprensa escrita e televisiva nas concessões de entrevistas. O registro biográfico encontra-se disponibilizado, dois exemplos são o livro "Tropicalista lenta luta", da Publifolha, e o premiado documentário dirigido por Fábio Matos Jr., "Fabricando Tom Zé”, de 2007.

Atualmente o músico alimenta um blog inaugurado em 2008 onde se comunica com internautas, nele comenta sobre assuntos diversos: política, cultura, literatura, música. Nele se expõe ao expor o ponto de vista acerca do controvertido mundo em que habitamos. Se acessado agora, pode-se compartilhar do músico alimentando as páginas virtuais com a análise do livro "O Século da Canção", de Luiz Tatit, onde predomina o caráter impressionista das análises e dos depoimentos, filtrados, portanto, pela subjetividade do individuo compartilhada com seu público. Constata-se uma das dimensões da obra do artista moderno, a celebridade individual, a conversão da história imediata do artista, a textualização da vida social, como estratégias para ampliar o alcance do discurso, no caso de Tom Zé, político e pedagógico.

Por fim, delineia-se o projeto didático que envolve procedimentos arriscados que, uma vez bem sucedidos na cristalização da forma, são de eficácia relativa na recepção da obra: humor, ironia e acentuada crítica política e social. Elementos que o insere como importante mediador e intérprete das transformações sociais, com a missão de iluminar as idéias de todas as classes sociais com a luz de suas inovações estéticas musicais. $\mathrm{O}$ risco fica por conta de tamanha transparência discursiva numa sociedade que tende a buscar o acalanto impregnado dos mitos que a engrandece. Pode dar certo, ainda mais quando legitimado pelo encantamento do estrangeiro, elevando o brio nacional. 


\section{Referências bibliográficas}

GARCIA CANCLINI, Nestor. "Culturas Híbridas: Estratégias para Entrar e Sair da Modernidade”. São Paulo, Editora da Universidade de São Paulo, 2006.

FERREIRA, Maria Nazareth. "Alternativas metodológicas para a produção científica”. São Paulo: CELACC-ECA/USP, 2006.

NAPOLITANO, Marcos. "História e Música". Belo Horizonte: Autêntica, 2002.

REVISTA CAROS AMIGOS. "Entrevista Risonha e Franca: Tom Zé, o Gênio de Irará". Disponível no site http:/www.tomze.com.br/ent5.htm, acessado em 9/9/ 2009).

SANCHES, Pedro Alexandre. "Tropicalismo: decadência bonita do samba". São Paulo: Boitempo Editorial, 2000.

SEMERARO, Giovani. "Gramsci e os novos embates da filosofia da práxis”. Aparecida: Idéias \& Letras, 2006.

ZÉ, Tom. “Tropicalista lenta luta”. São Paulo: Publifolha, 2003. Pág. 229

\section{Discografia/CDs}

"Estudando a Bossa Nova". Biscoito Fino, 2008.

"Estudando o Pagode". Trama, 2005.

"Imprensa Cantada". Trama, 2003.

"Jogos de Armar". TRAMA, 2001.

“Com defeito de Fabricação". Luaka Bop/WEA, 1998; TRAMA, 1999.

"No Jardim da Política". Documento histórico (show gravado ao vivo no Teatro Lira Paulistana), TZ, 1998.

"Parabelo". Grupo Corpo, 2003.

"The Hips OfTradition". Luaka Bop/Warner, 1992.

"Nave Maria". RGE, 1984.

"Correio da Estação do Brás”. Continental, 1978.

"Estudando o Samba". Continental, 1976.

"Todos os Olhos". Continental, 1973.

“Tom Zé”. Continental. Relançado em 1984 com o título Se o Caso é Chorar. Continental, 1972.

“Tom Zé”, 1968, Rozemblit.

\section{Vídeografia/DVD}

“Fabricando Tom Zé”. Filme de Décio Matos Jr. Spectra Nova, 2007.

"Ensaio Tom Zé". Entrevista da TV Cultura. Trama, 2007.

"Jogos de Armar". Registro de show. Trama, 2003. 
CAFUAS, GUETOS E SANTUÁRIOS - ATUALIZAÇÃO DO

SAGRADO NUM ARTISTA ICONOCLASTA: PRODUÇÃO,

RECEPÇÃO E REPERCUSSÃO DA OBRA DE TOM ZÉ

\section{Webgrafia}

http://www.tomze.com.br, acessado em 09/09/2009.

http://tomze.blog.uol.com.br, acessado em 09/09/2009.

Notas

${ }^{1}$ TOM ZÉ, em entrevista concedia à Revista Caros Amigos, 1999.

2 Idem.

${ }^{3}$ TOM ZÉ, em entrevista concedida à Revista Caros Amigos, 1999.

${ }^{4}$ Idem.

${ }^{5}$ TOM ZÉ, no documentário "Fabricando Tom Zé” (2007) 